\title{
The centella asiatica juice effects on DNA damage, apoptosis and gene expression in hepatocellular carcinoma (HCC)
}

\author{
Faridah Hussin ${ }^{1}$, Sima Ataollahi Eshkoor ${ }^{2}$, Asmah Rahmat ${ }^{*}$, Fauziah Othman ${ }^{1}$ and Abdah Akim ${ }^{1}$
}

\begin{abstract}
Background: This paper is to investigate the effects of Centella asiatica on HepG2 (human hepatocellular liver carcinoma cell line). Centella asiatica is native to the Southeast Asia that is used as a traditional medicine. This study aims to determine the chemopreventive effects of the Centella asiatica juice on human HepG2 cell line.

Methods: Different methods including flow cytometry, comet assay and reverse transcription-polymerase chain reaction (RT-PCR) were used to show the effects of juice exposure on the level of DNA damage and the reduction of cancerous cells. MTT assay is a colorimetric method applied to measure the toxic effects of juice on cells.

Results: The Centella asiatica juice was not toxic to normal cells. It showed cytotoxic effects on tumor cells in a dose dependent manner. Apoptosis in cells was started after being exposed for $72 \mathrm{hr}$ of dose dependent. It was found that the higher percentage of apoptotic cell death and DNA damage was at the concentration above $0.1 \%$. In addition, the juice exposure caused the reduction of c-myc gene expression and the enhancement of c-fos and c-erbB2 gene expressions in tumor cells.
\end{abstract}

Conclusions: It was concluded that the Centella asiatica juice reduced liver tumor cells. Thus, it has the potential to be used as a chemopreventive agent to prevent and treat liver cancer.

Keywords: Centella asiatica juice, DNA damage, Apoptosis, Gene expression, Hepatocellular carcinoma (HCC)

\section{Background}

Hepatocellular carcinoma ( $\mathrm{HCC})$ is one of the most common causes of cancer and cancer-related deaths worldwide that has been increased in the recent years [1]. HCC usually occurs due to viral hepatitis, hemochromatosis, alcohol-related liver disease, autoimmune hepatitis, nonalcoholic steatohepatitis (NASH), primary biliary cirrhosis $(\mathrm{PBC})$ and primary sclerosing cholangitis (PSC) [2]. HCC cancer mostly affects Southeast Asia and sub-Saharan Africa [1]. Scientists have demonstrated that more than two-thirds of cancer cases can be avoided or prevented by lifestyle modifications [3]. Herbal medicine can be used as a part of lifestyle to prevent and treat diseases [4], therefore, further studies are needed to clarify new biologically active compounds in the medicinal

\footnotetext{
* Correspondence: asmah@upm.edu.my

${ }^{1}$ Faculty of Medicine and Health Sciences, Universiti Putra Malaysia, 43400

Serdang, Selangor, Malaysia

Full list of author information is available at the end of the article
}

plants [5]. Centella asiatica or pegaga is one of the local medicinal plants in swampy areas including India, Sri Lanka, South Africa, China, the western South Sea Island, Australia, Madagascar, southern United States, the Southeast Asia such as Malaysia and Indonesia as well as insular and continental tropical America [6]. This plant has been claimed to have various medicinal effects that is consumed in different forms including tea, juice, pills and capsules [7]. It has been used to treat several problems such as insanity, asthma, leprosy, ulcers, eczema and wound healing. Centella asiatica has triterpene glycosides such as centellasaponin, asiaticoside, madecassoside, sceffoleoside, asiatic acid and madecassic acid. The most abundant triterpene glycoside in the extracted juice is asiaticoside, which can be transformed into asiatic acid. This compound has cytotoxic effects on fibroblast cells as well as the ability to induce apoptosis in different sorts of cancer [8].

Biological activity of compounds present in the Centella asiatica plant can alter the expression level of

\section{Biomed Central}




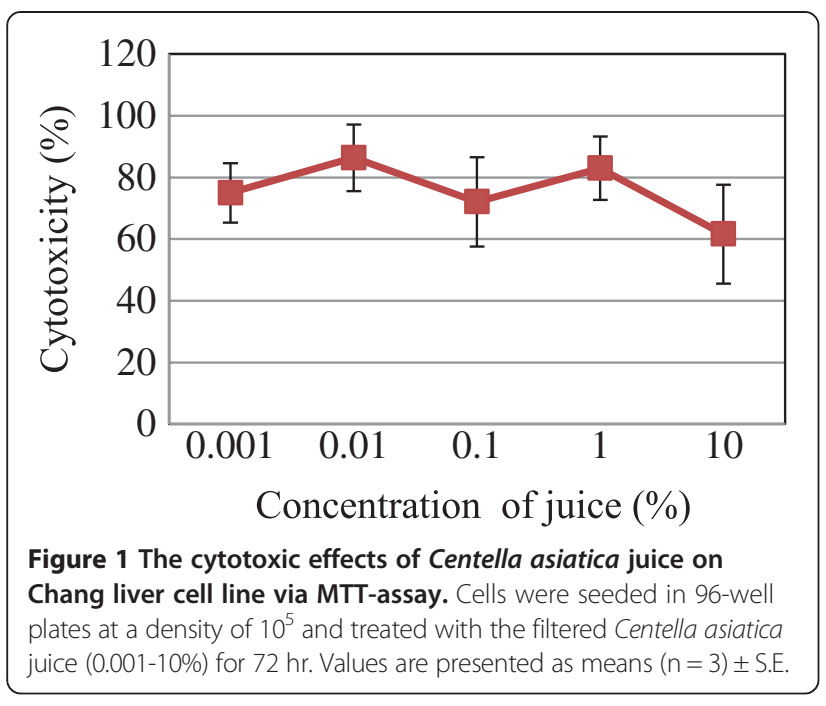

different genes [9]. For example, the extracted juice can change the expression of c-myc, c-fos and c-erbB2 oncogenes in exposed cells. C-myc gene promotes cell cycle progression in cells $[10,11]$. C-fos gene is normally involved in cell cycle regulation, cell differentiation and transformation [12] that is induced by c-erbB2 gene [13]. This study was conducted to identify the cytotoxic and chemopreventive effects of Centella asiatica juice on HCC cells assessed at different concentrations.

\section{Methods}

\section{Chemicals}

Two cell lines, human normal liver cell line (Chang liver) and hepatocellular carcinoma cell line (HepG2) were purchased from American Type Culture Collection (ATCC), Rockville, Maryland, USA. Furthermore, the materials of Dulbecco's modified Eagle's medium (DMEM), dimethyl sulfoxide (DMSO), fetal calf serum, penicillin, streptomycin, PBS-EDTA, trypsin and propidium iodide were bought from Sigma Chemical Co. (Gibco, USA). Trypan blue dye and 3-(4,5-dimethylthiazol-2-yl)-2,5-diphenyltetrazolium bromide (MTT) were purchased from Sigma Chemical Company (St. Louis, MO, USA). In addition, the falcon flasks for cell culture were taken from Nunc Co. Denmark. The MasterPure ${ }^{\mathrm{TM}}$ RNA Purification Kit was purchased from Epicentre Technologies (Becton Dickinson Corp., Rutherford, New Jersey, USA) to purify RNA. The used chemicals were with the highest pure grade available.

\section{Preparation of centella asiatica juice}

The project was undertaken at the Faculty of Medicine and Health Sciences in Universiti Putra Malaysia (UPM). Optimum formulation and processing parameter for herbal juice preparation was selected from the response surface methodology analysis. Centella asiatica plant (Voucher No. SK 533/03) locally named pegaga cina, a native and well known plant was collected from an Herbal Farm in Melaka, Malaysia. After collection, plant was weighed, washed, cut into small pieces and then deposited at the Institute of Bioscience, UPM. It was mixed with filtered water containing $0.1 \%(\mathrm{w} / \mathrm{w})$ sodium metabisulphite. After that, the dried plant was grounded into very fine particles using mechanical grinder. $14 \%$ of puree was mixed with $14 \%$ honey, $0.2 \%(\mathrm{w} / \mathrm{w})$ xanthan gum and homogenized using Homogenizer IKA II for $5 \mathrm{~min}$. Mixture was pasteurized at $80^{\circ} \mathrm{C}$ for $3 \mathrm{~min}$ using jacketed heater and final products were hot-filled into sterilized glass bottle, cooled to a room temperature under running water and kept chilled for analysis. The herbal extract sterilization can be done by using both high temperature and pressure.

\section{Cell culture and treatment}

Cell cultures were carried out in the Microbiological Safety cabinet ERLA Esc Series Class II. Cells grown in DMEM supplemented with $10 \%$ fetal bovine serum (GIBCO BRL), 1\% penicillin and streptomycin were incubated in a humidified incubator with 5\% CO2 and 95\% air at $37^{\circ} \mathrm{C}$. Media of the culture environment was changed

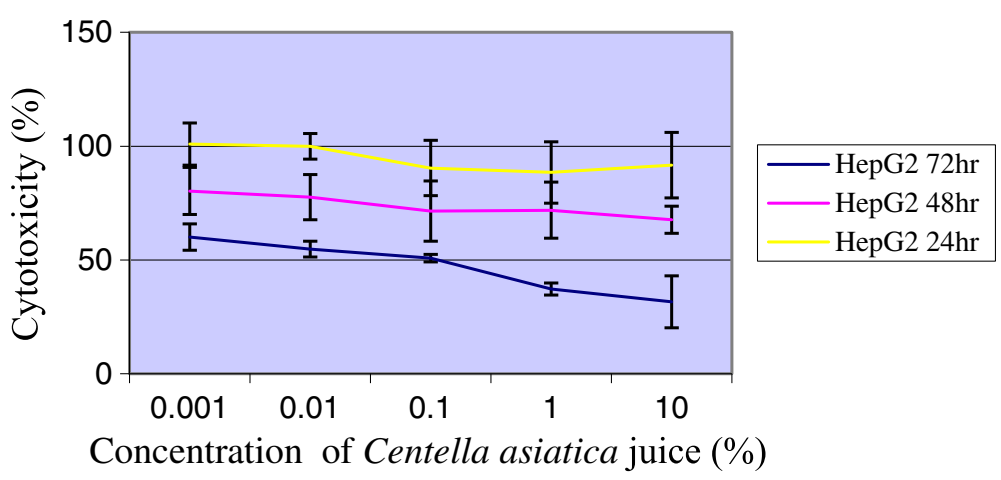

Figure 2 The cytotoxic effects of Centella asiatica juice on HepG2 cell line via MTT-assay. Cells were seeded in 96-well plates at a density of $10^{5}$ and treated with filtered Centella asiatica juice (0.001-10\%) for 24,48 and $72 \mathrm{hr}$. Values are presented as means $(n=3) \pm$ S.E. 


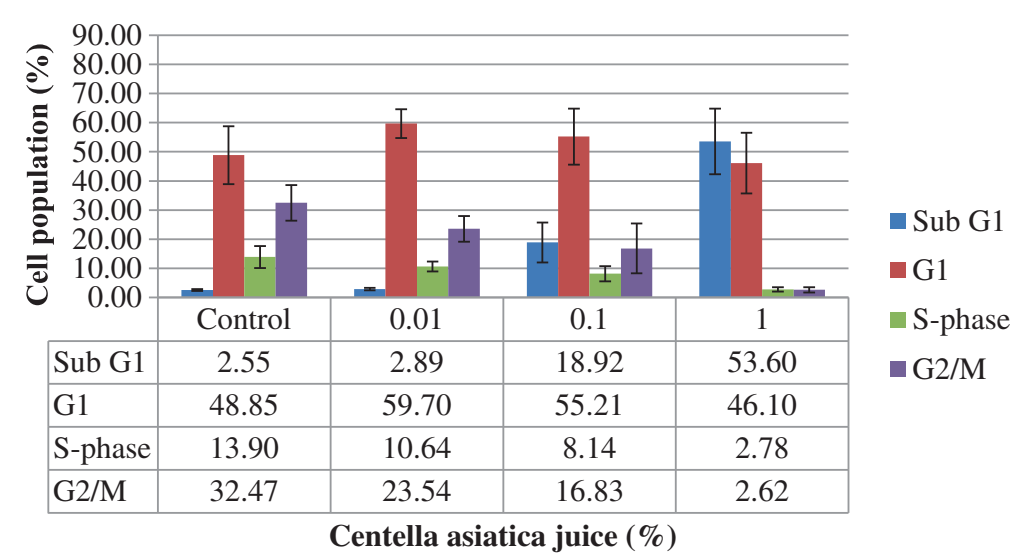

Figure 3 Cell cycles profiles of HepG2 cells untreated and treated with the Centella asiatica juice (CAJ) and subsequently stained with propidium iodide. Cells were exposed to $0.01,0.1$ and $1.0 \%$ of CAJ for $72 \mathrm{hr}$.

frequently each three days. The cell cultures were regularly examined using inverted microscope. For treatment, the suitable amount of cells (about $1 \times 10^{6}$ cells $\left./ \mathrm{ml}\right)$ was pipetted into the cell culture flasks (Nunc, Denmark), which were provided three for each concentration. Then, these flasks were incubated in a $5 \% \mathrm{CO}_{2}$ incubator (Sanyo, Japan) at $37^{\circ} \mathrm{C}$ for $24 \mathrm{hr}$. HepG2 cells were treated with the Centella asiatica juice at $0.01,0.1$, and $1 \%$ concentrations. Cells were left in a $5 \% \mathrm{CO} 2$ incubator at $37^{\circ} \mathrm{C}$ for $72 \mathrm{hr}$. The harvested cells in the flasks were used to conduct experiments.

\section{MTT assay}

The MTT assay was used to analyze cell proliferation among cells [14]. HepG2 and Chang cell lines harvested in flasks were detached by trypsin and stained with trypan blue to determine the viability by counting the cells using a haemocytometer under the inverted microscope (Olympus CK40, Japan). Cells were diluted with DMEM to yield a suspension at a concentration of $1 \times 10^{5}$ cells $/ \mathrm{ml}$ and then $100 \mu \mathrm{l}$ of suspension was pipetted into a 96-well micro titer plate (Nunc, Denmark). After that, this plate was incubated in a $5 \% \mathrm{CO} 2$ incubator at $37^{\circ} \mathrm{C}$ for $24 \mathrm{hr}$ to allow the cells attached to well. After incubation, cells were treated with $100 \mu$ l of sterile sample (filter using $0.2 \mu \mathrm{m}$; Schleicher and Schuell) prepared at different concentration levels of $0.001,0.01,0.1,1.0$ and $10 \%$. The 96 well-plate was then kept in $\mathrm{a} \mathrm{CO}_{2}$ incubator for 24, 48 and $72 \mathrm{hr}$. After that, $10 \mu \mathrm{l}$ of MTT was pipetted into wells and incubated again for $4 \mathrm{hr}$. Finally, $100 \mu \mathrm{l}$ of Dimethyl sulfoxide (DMSO) was added into wells and the absorbance was read using Microplate absorbance reader Anthos Zenyth $340 \mathrm{~s}$ at wavelengths between 500 and $600 \mathrm{~nm}$. The calculation of absorbance for each concentration of juice was compared with untreated control.

\section{Flow cytometry}

After the treatment of cells, DNA content was measured using Flow cytometer Becton Dickinson FACStarPLUS. Cells were initially treated by different concentrations of the Centella asiatica juice including $0.01,0.1$, and $1 \%$ and then incubated in $5 \% \mathrm{CO} 2$ at $37^{\circ} \mathrm{C}$ for $72 \mathrm{hr}$. Cells were fixed by adding the absolute ethanol, followed by
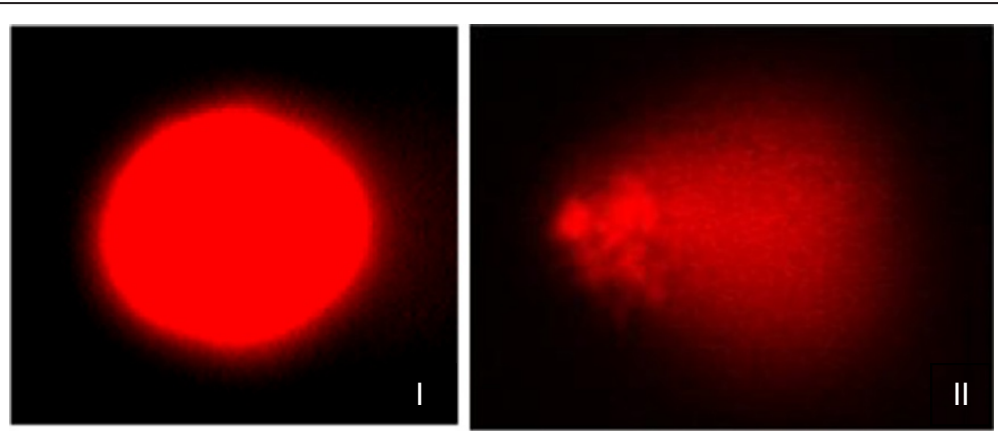

Figure 4 Fluorescence image of red-stained comets from control (I) and juice treated (II) HepG2 cells (20x magnification). 


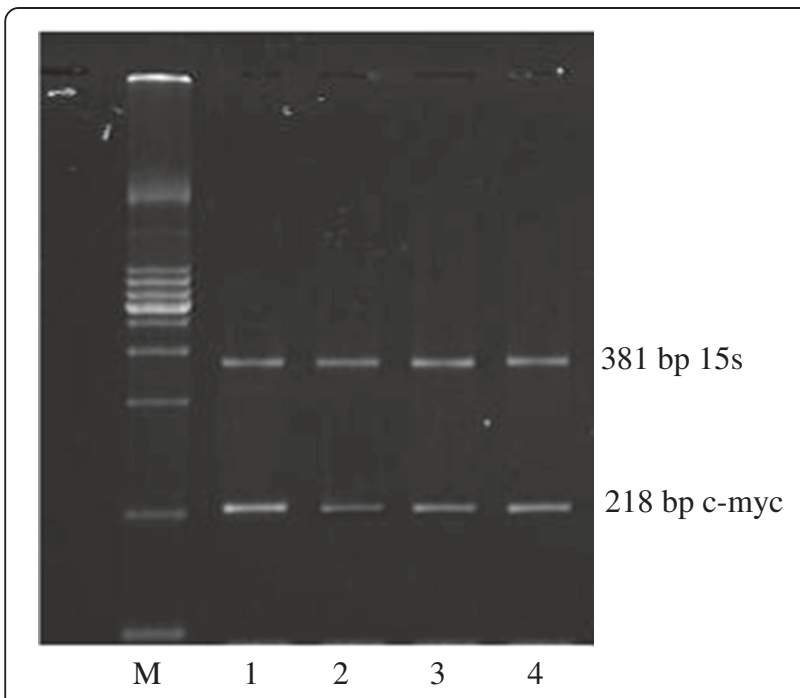

Figure 5 Expression of c-myc oncogene in untreated (1) and treated $(2,3,4)$ HepG2 cancer cell lines with $0.01,0.1,1.0 \%$ Centella asiatica juice respectively for $72 \mathrm{hr}$. Note the expression of c-myc band before (1) and after treatment $(2,3,4)$. Lane $M$ is the DNA ladder for marker and act as comparison to the oncogene band.

adding $200 \mu \mathrm{g} / \mathrm{ml}$ of DNase-free Rnase A and incubated at $37^{\circ} \mathrm{C}$ for $30 \mathrm{~min}$. After this step, cells were permeabilized using Trition X-100, combined with $100 \mu \mathrm{l}$ of $1 \mathrm{mg} / \mathrm{ml}$ propidium iodide as a light sensitive and incubated at room temperature for 5-10 min. Samples (untreated and treated cells) were placed into $12 \times 75 \mathrm{~mm}$ Falcon tubes and read using a Becton Dickinson FACStarPLUS (Becton Dickinson, Franklin Lakes, NJ). The presence of cells in sub-G1 phase was indicator of apoptotic cell death.

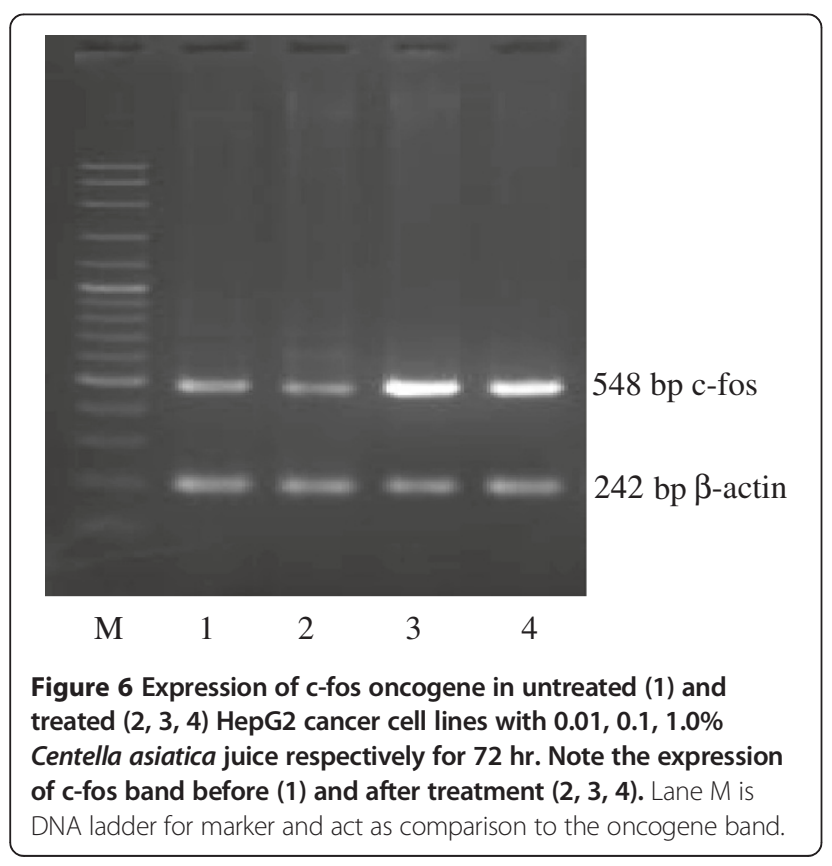

\section{Comet assay}

Comet assay was used to evaluate DNA damage level in the treated cells compared to controls. This experiment was performed according to a modified protocol, which was basically suggested by McKelvey-Martin and co-workers [15]. The assay was carried out under dimmed light to prevent cell damage from UV [16]. Frosted microscope slides were covered with $80 \mu \mathrm{l}$ of $1 \%$ normal melting agarose (NMA) in Tris-acetate-EDTA (TAE) buffer at $45^{\circ} \mathrm{C}$, then covered with cover slip and kept at $4^{\circ} \mathrm{C}$ for 5 min until agarose had been solidified. Approximately $75 \mu \mathrm{l}$ of $0.5 \%$ low melting point agarose (LMA) at $37^{\circ} \mathrm{C}$ was added to the pellet of cells suspended in $10 \mu \mathrm{l}$ of PBS and then the cell suspension was rapidly pipetted onto the first (NMA) agarose layer of slides. These slides were immersed in freshly prepared, cold lysis solution added with $1 \%$ triton $\mathrm{X}-100$ at $4^{\circ} \mathrm{C}$ for $1 \mathrm{hr}$ in a dark place. After that, slides were removed, drained and immersed in electrophoresis buffer $\left(10 \mathrm{~N} \mathrm{NaOH}, 200 \mathrm{mM} \mathrm{Na}_{2}\right.$ EDTA, pH > 12) at $4^{\circ} \mathrm{C}$ for 20-60 min in the dark to unwind DNA. Then, slides were placed flat on a gel tray with aligned equidistant from the electrodes. The electrophoresis was conducted at $25 \mathrm{~V}$ adjusted to $300 \mathrm{~mA}$ for $20 \mathrm{~min}$. After that, slides were stained with $50 \mu \mathrm{l}$ of $20 \mu \mathrm{g} / \mathrm{ml}$ ethidium bromide and then viewed using fluorescence microscope.

Analysis was performed immediately after staining under a Leica Epifluorescence microscope equipped with an excitation filter of 515-560 nm (Bellows Falls, VT, USA) with magnification of $400 \times$. For each sample, 15-50 of cells were analysed. Slides were scored by moving from top to bottom slide along to avoid analysis of same comet twice. Parameters of tail length (distance from the head center to the end of the tail) and tail migration (distance from the end of the head to the end of the tail) were used to estimate DNA migration.

\section{Gene expression and RT-PCR}

The amplification and detection of mRNA expression of oncogenes in HepG2 cell line was done using primer of oncogenes and primer of housekeeping genes. Total RNA was extracted from the cells treated with the Centella asiatica juice. MasterPure ${ }^{\mathrm{TM}}$ RNA Purification Kit from Epicentre Technologies (Becton Dickinson Corp., Rutherford, New Jersey, USA) was used to purify RNA. The extracted RNA was treated with DNase and then used to synthesize cDNA by One Step RT-PCR according to RT-PCR Premix protocol (Mbiotech, Korea). In this study, c-myc, c-fos and c-erbB2 oncogenes were studied. Housekeeping genes including $ß$-actin and $15 \mathrm{~s}$ were selected to be internal positive controls.

PCR primers for c-myc gene were obtained from a published article [17]. The primers used for c-fos, c-erbB2, $15 \mathrm{~s}$ and $ß$-actin genes were designed. The sense primers for c-fos, c-erbB2, c-myc, $15 \mathrm{~s}$ and $ß$-actin genes were 


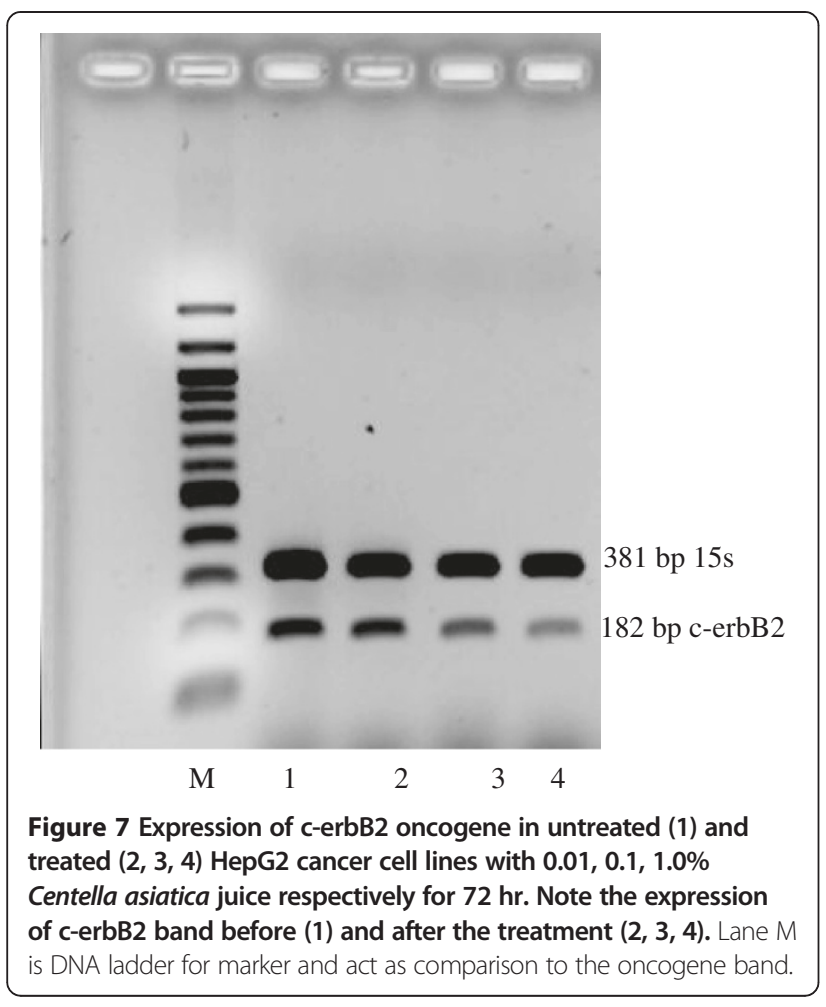

5'-GGATAAGATGGCTGCAGCCAAGTGC-3', 5' -GA TGTATTT-GATGGTGACCT-3', 5' -CAAGAGGCGAA CACACCACGTCT-3', 5'-TTCCGCAAGTTCAC-CTA CC-3' and 5'-CGTGGGCGCCCTAGGCACCA-3' respectively. The antisense primers for c-fos, c-erbB2, c-myc, $15 \mathrm{~s}$ and 3 -actin genes were 5 '-AAGGAAGACGTGTAAGCAG TGCAG-C-3', 5' -ATCTGGCTGGTTCACATATT-3', 5' AACTGTTCTCGTCGTTTCCGCAA-3', 5'-C-GGGCCG GCCATGCTTTACG-3' and 5'-TTGGCCTTAGGGTTC AGGGGGG-3' respectively.

The expression of oncogenes was assessed at the low, medium and high concentrations of juice. Oncogenes including c-myc, c-fos and c-erbB2 were amplified along with either $15 \mathrm{~s}$ or $\beta$-actin housekeeping genes to detect their expression levels. Each PCR reaction included $1 \mathrm{ng}-2 \mu \mathrm{g}$ total RNA, $1 \mu \mathrm{l}$ of each primer $(10 \mathrm{pmol} / \mu \mathrm{l})$, $10 \mu \mathrm{l}$ of One Step RT-PCR Premix Master Mix (5×) and

Table 1 Ratio of target genes to reference genes expression in untreated and treated

\begin{tabular}{cccc}
\hline $\begin{array}{c}\text { Concentration of Centella } \\
\text { asiatica juice (\%) }\end{array}$ & \multicolumn{3}{c}{$\begin{array}{c}\text { Expression of oncogenes } \\
\left.\text { in HepG2 (INT/mm }{ }^{2}\right)\end{array}$} \\
\hline 0 & C-myc & C-fos & C-erbB2 \\
0.01 & 1.43 & 1.2 & 2.54 \\
0.1 & 0.69 & 1.0 & 2.16 \\
1.0 & 0.69 & 2.2 & 3.11 \\
\hline
\end{tabular}

HepG2 cell line with Centella asiatica juice.
$7 \mu \mathrm{l}$ of RNase-free water in a single PCR reaction tube to produce a volume of $20 \mu \mathrm{l}$. The reverse transcription was performed at $42^{\circ} \mathrm{C}$ within $30 \mathrm{~min}$ in one cycle followed by RT inactivation and pre-denaturation at $96^{\circ} \mathrm{C}$ for $3 \mathrm{~min}$. The PCR reaction was continued under the same conditions within 30 cycles for all samples. The cycles were settled on a denaturation stage at $94^{\circ} \mathrm{C}$ for $30 \mathrm{~s}$, annealing temperature at $50-60^{\circ} \mathrm{C}$ for $30 \mathrm{~s}$ found through the gradient PCR, an extension phase at $72^{\circ} \mathrm{C}$ for $60 \mathrm{~s}$ and a final extension at $72^{\circ} \mathrm{C}$ for $10 \mathrm{~min}$ followed the reaction last cycle.

After PCR was finished, samples were stored at $4^{\circ} \mathrm{C}$ until use. A negative control without DNA template was carried out in each run. After the completion of PCR, products were analyzed by running on $1.5 \%$ agarose gel electrophoresis. In addition, DNA ladder of $100 \mathrm{bp}$ (Bioline, USA) was used to identify the sizes of products. The visualization of DNA was done by placing the gel onto UV light source. The quantity of RT-PCR bands were analyzed based on the intensity under Gel Doc 2000 software (BIO-RAD). The ratios of target genes to reference genes (housekeeping gene) were calculated and compared.

\section{Statistical analyses}

Data were analysed using the Statistical Package for the Social Sciences (SPSS) software version 19.0 (Chicago, IL, USA). The critical level for rejection of the null hypothesis was considered to be a $\mathrm{p}$ value of $5 \%$, two-tailed. Values were expressed as mean \pm SD. The Data were statistically analyzed using one way-ANOVA followed by Tukey's post Hoc t-test analysis.

\section{Results}

It was found that the increase in the doses of Centella asiatica juice up to $10 \%$ had no cytotoxic effects against Chang cell line when cells were incubated up to $72 \mathrm{hr}$ (Figure 1). The results showed that the inhibitory effects of juice on proliferation of HepG2 cancer cell line was associated with concentration doses and exposure duration time. The cytotoxicity started at a concentration dose of $0.1 \%$ when HepG2 cells were treated and incubated up to $72 \mathrm{hr}$ (Figure 2). This effect showed a chemopreventive activity of juice against liver tumor cells. Furthermore, flow cytometry showed the rate of cell death and growth arrest in the treated cells with juice.

Apoptosis increased in HepG2 cells treated with juice when they were incubated for $72 \mathrm{hr}$. The cell death in HepG2 cell line was 8 and 21 times more than controls when they were treated with respective concentrations 0.1 and $1 \%$. By increasing the juice concentrations, cell population in the G2/M arrest and S-phase decreased. In addition, the juice treatment increased cells in the Sub G1 phase between 3\% and 54\% and decreased cells 
in the G2/M phase between 33\% and 3\%. Furthermore, the G1 phase slightly increased after the treatment with $0.01 \%$ concentration and gradually decreased with the increase of concentrations (Figure 3). The treatment with 0.1 and $1 \%$ concentrations of juice significantly increased DNA damage in HepG2 cells $(\mathrm{p}<0.05)$ (Figure 4).

$\mathrm{C}$-myc, c-fos and c-erbB2 oncogenes were detected at 218,584 and 182 bp respectively whereas the $15 \mathrm{~S}$ and $\beta$-actin housekeeping genes were detected at 381 and 242 bp respectively (Figures 5, 6 and 7). After the treatment with $0.01,0.1$ and $1.0 \%$ concentrations of the Centella asiatica juice, c-myc gene was suppressed in HepG2 cells. The expression of c-fos and c-erbB2 genes increased at the concentrations of $0.1 \%$ and above (Table 1 ). The treatment of cells with juice showed that the expression level of c-fos increased by $83 \%$ in both concentrations of 0.1 and $1.0 \%$. Meanwhile, these respective concentrations increased the expression of c-erbB2 gene by $22 \%$ and $16 \%$.

\section{Discussion}

Plant products contain natural anticancer and chemopreventive agents, which can protect body against cancer [18]. The cytotoxic effects of Centella asiatica juice on HepG2 cell line suggests the susceptibility of cells for being treated with juice. Such effect of juice is probably due to the compounds having cytotoxic and anti-tumour properties [19]. The Centella asiatica compounds can cause apoptosis $[20,21]$ to protect cells against neurotoxicity. Furthermore, apoptosis can inhibit the promotion [22] and invasion [23] of cells in different types of tumors [24,25]. Such effects were related to dose concentration and exposure duration time. The protective effects of juice [26] against cancer is most likely due to the effects of antioxidants [27,28] and apoptotic cell death [20,21]. Thus, Centella asiatica can be used as a potential natural chemopreventive agent to combat liver cancer. Our results confirmed the previous research [29] indicating that the Centella asiatica juice has no potent cytotoxic ability and toxic effects on healthy cells.

The effects of juice were assessed on c-myc, c-fos and c-erbB2 genes as genes involved in cell cycle control. It was found that the Centella asiatica juice reduced c-myc gene in HepG2 cells. It seems that this condition was a response to sustain DNA damage in HepG2 cells during DNA fragmentation in apoptosis [30,31]. Down regulation of c-myc gene may affect apoptosis due to the following conditions; serum starvation, chemically induced and exposed to viruses [32,33]. On the other hand, upregulation of c-myc oncogene has been found in human hepatoma cells as well [34]. Such variety suggests the contribution of different expression of c-myc gene to the regulation of apoptotic cell death [35], which can be related to the type of stimuli required for starting and efficient induction of apoptosis [36,37].
In the current study, the treatment of HepG2 cells with the Centella asiatica juice increased c-fos gene expression, which is more likely due to stimulating effects of juice [38-40] on the increased level of apoptosis, DNA breakage [38-40], the apoptotic late response of cells [41] and c-myc-mediated apoptosis [34]. In addition, the Centella asiatica juice increased the expression of c-erbB2 gene in HepG2 cells probably due to the association of c-erbB2 gene with differentiation and apoptosis process. It has been documented that a complex integration of signal transduction pathways of proto-oncogenic proteins can mediate apoptosis process in different cells through decreased or increased expression, which depends on cell-type specificity and nature of apoptotic stimuli such as drug or compounds [42]. The induction of apoptosis in HepG2 can be explained by the interference of Centella asiatica juice with oncogenes in liver cancer cells. It shows that genetic alterations and the impairment of oncogene activities may associate with apoptosis [42].

\section{Conclusions}

It was concluded that the Centella asiatica juice inhibited the proliferation of a malignant HepG2 cell line through apoptosis or programmed cell death. Flow cytometry and comet assay analysis showed that juice increased DNA damage in HepG2 cells when they were exposed for $72 \mathrm{hr}$. In addition, juice reduced the level of c-myc gene expression but increased the level of c-fos and c-erbB2 genes in HepG2 cells. Such changes increased apoptosis in the liver tumor cells. It was concluded that the Centella asiatica juice can maintain the health of liver and reduce the incidence of liver cancer. Further investigations are needed in future to identify the exact effects of this juice on HepG2 cells regarding the reduction and treatment of liver cancer.

\section{Abbreviations}

ATCC: American type culture collection; DMEM: Dulbecco's modified eagle's medium; DMSO: Dimethyl sulfoxide; HCC: Hepatocellular carcinoma; LMA: Low melting point agarose; NASH: Nonalcoholic steatohepatitis; NMA: Normal melting agarose; PBC: Primary biliary cirrhosis; PSC: Primary sclerosing cholangitis.

\section{Competing interests}

Authors declare that there are no competing interests in relation to this manuscript.

\section{Authors' contributions}

$\mathrm{FH}$ : preparation of draft, contribution to conception, design, acquisition of data, analysis and interpretation of data. SAE: involved in conception, drafting the manuscript and revising it critically. AR: contribution to conception, design, data analysis and final approval of the version for publishing. FO: contribution to conception and design of study. AA: contribution to conception and design of study. All authors read and approved the manuscript.

\section{Acknowledgement}

Authors would like to thank laboratory staff for providing support during the study. 


\section{Author details}

${ }^{1}$ Faculty of Medicine and Health Sciences, Universiti Putra Malaysia, 43400 Serdang, Selangor, Malaysia. ${ }^{2}$ Institute of Gerontology, Universiti Putra Malaysia, 43400 Serdang, Selangor, Malaysia.

Received: 27 June 2013 Accepted: 9 December 2013 Published: 20 January 2014

\section{References}

1. Parikh S, Hyman D: Hepatocellular cancer: a guide for the internist. Am J Med 2007, 120(3):194-202.

2. Olsen SK, Brown RS, Siegel AB: Review: hepatocellular carcinoma: review of current treatment with a focus on targeted molecular therapies. Therap Adv Gastroenterol 2010, 3(1):55-66.

3. Oliveria SA: The role of epidemiology in cancer prevention. Soc Exp Biol Med 1997, 216(2):142-150.

4. Firenzuoli F, Gori L: Herbal medicine today: clinical and research issues. eCAM 2007, 4(Suppl 1):37-40.

5. Yoo HH, Park JH, Kwon SW: In vitro cytotoxic activity of some Korean medicinal plants on human cancer cell lines: enhancement in cytotoxicity by heat processing. Phytother Res 2007, 21(9):900-903.

6. Rosalizan M, Rohani M, Khatijah I, Shukri M: Physical characteristics, nutrient contents and triterpene compounds of ratoon crops of Centella asiatica at three different stages of maturity. J Trop Agric Food Sci 2008, 36(1):43-51.

7. Mahanom H, Azizah A, Suhaila M, Nazamid S, Maznah I, Hair BM: Effect of Centella asiatica extract and powder on hydrogen peroxide-treated Sprague-Dawley rats. J Trop Agric Food Sci 2011, 39(1):000-000.

8. Pittella F, Dutra RC, Junior DD, Lopes MT, Barbosa NR: Antioxidant and cytotoxic activities of Centella asiatica (L) Urb. Int J Mol Sci 2009, 10(9):3713-3721.

9. Coldren CD, Hashim P, Ali JM, Oh S-K, Sinskey AJ, Rha C: Gene expression changes in the human fibroblast induced by Centella asiatica triterpenoids. Planta Med 2003, 69(8):725-732.

10. Amati B, Frank SR, Donjerkovic D, Taubert S: Function of the c-myc oncoprotein in chromatin remodeling and transcription. Biochim Biophys Acta 2001, 1471(3):135-145.

11. Jonas AN, Kirsteen HM, Ulrich BK, Helene P, Troy AB, Cleveland JL: Mnt loss triggers c-myc transcription targets proliferation on apoptosis and transformation. Mol Cell Biol 2004, 24(4):1560-1569.

12. Tesarik J, Garrigosa L, Mendoza C: Estradiol modulates breast cancer cell apoptosis: a novel nongenomic steroid action relevant to carcinogenesis. Steroids 1999, 64(1-2):22-27.

13. Scott GK, Dodson JM, Montgomery PA, Johnson RM, Sartup JC: p185HER2 signal transduction in breast cancer cells. J Biol Chem 1991, 266(22):14300-14305.

14. Jiang $Y$, Zhang $Y$, Luan J, Duan H, Zhang F, Yagasaki K, Zhang G: Effects of bufalin on the proliferation of human lung cancer cells and its molecular mechanisms of action. Cytotechnology 2010, 62(6):573-583.

15. McKelvey-Martin VJ, Green MHL, Schmezer P, de Mjo BMP, Collinns M: The single cell gel electro (comet assay): a European review. Mutat Res 1993, 288(1):47-63.

16. Eshkoor SA, Ismail P, Abd. Rahman S, Moin S, Adon MY: The association of DNA damage level with early age at the occupational exposure in the mechanical workshops workers. Asian J Biotechnol 2012, 4(2):83-91.

17. Coucouvanis EC, Jones PP: Changes in protooncogene expression correlated with general and sex specific differentiation in murino primordial germ cells. Mech Dev 1993, 42(1-2):49-58.

18. Cragg GM, Newman DJ: Plants as a source of anti-cancer agents. J Ethnopharmacol 2005, 100(1):72-79.

19. Babu TD, Kuttan G, Padikkala J: Cytotoxic and anti-tumor properties of certain types of Umbelliferae with special reference to Centella asiatica (L.) Urban. J Ethnopharmacol 1995, 48(1):53-57.

20. Huang $\mathrm{YH}$, Zhang $\mathrm{SH}$, Zhen RX: Asiaticoside inducing apoptosis of tumor cells and enhancing anti-tumor activity of vincristine. Display Settings 2004, 23(12):1599-1604.

21. Park YK, Kim Y, Park E, Kim JS, Kang M-H: Estimated flavonoids intake in Korean adults using semiquantitative food frecuency questionnaire. The Korean Journal of Nutrition 2002, 35(10):1081-1088.

22. Konoshima T, Takasaki M, Tokuda H, Masuda K, Masuda Y, Arai Y, Shiojima K, Ageta H: Anti-tumor-promoting activities of triterpenoids from ferns. I. Biol Pharm Bull 1996, 19(7):962-965.

23. Cha HJ, Bae SK, Lee HY, Lee OH, Sato H, Seiki M: Anti-invasive activity of ursolic acid correlates with the reduced expression of matrix metalloproteinase-9
(MMP-9) in HT1080 human fibrosarcoma cell. Cancer Res 1996, 56(10):2281-2284

24. Jew SS, Yoo CH, Lim DY, Kim H, Mook-Jung I, Jung MW: Structure activity relationship study of Asiatic acid derivatives against beta amyloid (A beta)-induced neurotoxity. Bioorg Med Chem Lett 2000, 10(2):119-121.

25. Lee MK, Kim SR, Sung SH, Lim D, Kim H, Choi H: Asiatic acid derivatives protect cultured cortical neurons from glutamate-induced excitotoxicity. Res Commun Mol Pathol Pharmacol 2000, 108(1-2):701-708.

26. Babykutty S, Padikkala J, Sathiadevan PP, Vijayakurup V, Azis TKA, Srinivas P, Gopala S: Apoptosis induction of Centella asiatica on human breast cancer cells. Afr J Tradit Complement Altern Med 2009, 6(1):9.

27. Cai Y, Lua Q, Sun M, Corke H: Antioxidant activity and phenolic compounds of 112 traditional Chinese medicinal plants associated with anticancer. Life Sci 2000, 74(17):2157-2184

28. Park YK, Park E, Kim J-S, Kang M-H: Daily grape juice consumption reduces oxidative DNA damage and plasma free radical levels in healthy Koreans. Mutation Research/Fundamental and Molelcular Mechanism in Mutagenesis 2003, 529(1-2):77-86.

29. Geran R: Protocols for screening chemical agents and natural products against animal tumors and other biological systems. Cancer Chemother Rep 1972, 3:51-61.

30. Magnet KJ, Orr MS, Cleveland JL, Rodriguez-Galindo C, Yang H, Yang C, Di Y-M, Jain PT, Gewirtz DA: Suppression of c-myc expression and c-Myc function in response to sustained DNA damage in MCF-7 breast tumor cells. Biochem Pharmacol 2001, 62(5):593-602.

31. Fornari FA Jr, Jarvis WD, Grant S, Orr MS, Randolph JK, White F, Mumaw VR, Lovings ET, Freeman RH, Gewirtz DA: Induction of differentiation and growth arrest associated with nascent (nonoligosomal) DNA fragmentation and reduced c-myc expression in MCF-7 human breast tumor cells after continuous exposure to a sublethal concentration of doxorubicin. Cell Growth Differ 1994, 5(7):723.

32. Landay M, Oster SK, Khosravi F, Grove LE, Yin X, Sedivy J: Promotion of growth and apoptosis in c-myc nullizygous fibroblasts by other members of the myc oncoprotein family. Cell Death Differ 2000, 7(8):697-705.

33. Li D, Tonya M, Shinji S: AFP-L3: a new generation of tumor marker for hepatocellular carcinoma. Clinica Chemica Acta 2001, 313(1-2):15-19.

34. Kalra N, Kumar V: C-fos is a mediator of the c-myc-induced appoptitic signaling in serum-deprived hepatoma cells via the p38 mitogen-activated protein kinase pathway. J Biol Chem 2004, 279(24):25313-25319.

35. Thompson EB: The many roles of c-Myc in apoptosis. Annu Rev Physiol 1998, 60(1):575-600.

36. Dong JM, Naito Y, Tsuruo T: C-myc play a role in cellular susceptibility to death receptor-mediated and chemotherapy-induced apoptosis in human monocytic leukemia U937 cells. Oncogene 1997, 15(6):639-647.

37. Tiberio L, Maier JAM, Schiaffonati L: Down-modulation of c-myc expression by phorbol ester protects CEM T leukaemia cells from starvation-induced apotosis: role of ornithine decarboxlase and polyamines. Cell Death Differ 2001, 8(10):967-976.

38. Lackinger D, Kaina B: Primary mouse fibroblasts deficient for c-fos, p53 or for both proteins are hypersensitive to UV light and alkylating agent-induced chromosomal breakage and apoptosis. Mutat Res 2000, 457(1-2):113-123.

39. Hu L, Hatano M, Ruther U, Tokuhisa T: Overexpression of c-Fos induces apoptosis of CD43+ pro-B cells. J Immunol 1996, 157(9):3804-3811.

40. Inada K, Okada S, Phuchareon J, Hatano J, Sugimoto T, Moriya H, Tokuhisa T: C-Fos induces apoptosis in germinal center B cells. J Immunol 1998, 161(8):3853-3861.

41. Kaina B, Haas S, Kappes $\mathrm{H}$ : A general role for c-fos in cellular protection against DNA-damaging carcinogens and cytostatic drugs. Cancer Res 1997, 57(13):2721-2731.

42. Robson S, Ward L, Brown H, Turner H, Hunter E, Pelengaris S, Khan M: Deciphering c-MYC-regulated genes in two distinct tissues. BMC Genomics 2011, 12(1):476.

doi:10.1186/1472-6882-14-32

Cite this article as: Hussin et al:: The centella asiatica juice effects on DNA damage, apoptosis and gene expression in hepatocellular carcinoma (HCC). BMC Complementary and Alternative Medicine 2014 14:32. 